\title{
Development and Patterning of the Cochlea: From Convergent Extension to Planar Polarity
}

\author{
Mireille Montcouquiol ${ }^{1,2}$ and Matthew W. Kelley ${ }^{3}$ \\ ${ }^{1}$ INSERM, Neurocentre Magendie, U1215, F-33077 Bordeaux, France \\ ${ }^{2}$ University of Bordeaux, Neurocentre Magendie, U1215, F-33077 Bordeaux, France \\ ${ }^{3}$ Laboratory of Cochlear Development, National Institute on Deafness and Other Communication Disorders, \\ National Institutes of Health, Bethesda, Maryland 20892 \\ Correspondence: mireille.montcouquiol@inserm.fr; kelleymt@nidcd.nih.gov
}

Within the mammalian cochlea, sensory hair cells and supporting cells are aligned in curvilinear rows that extend along the length of the tonotopic axis. In addition, all of the cells within the epithelium are uniformly polarized across the orthogonal neural-abneural axis. Finally, each hair cell is intrinsically polarized as revealed by the presence of an asymmetrically shaped and apically localized stereociliary bundle. It has been known for some time that many of the developmental processes that regulate these patterning events are mediated, to some extent, by the core planar cell polarity (PCP) pathway. This article will review more recent work demonstrating how components of the PCP pathway interact with cytoskeletal motor proteins to regulate cochlear outgrowth. Finally, a signaling pathway originally identified for its role in asymmetric cell divisions has recently been shown to mediate several aspects of intrinsic hair cell polarity, including kinocilia migration, bundle shape, and elongation.

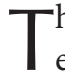
he mammalian cochlea is a remarkable example of cellular engineering. Selective pressures related to the ability to perceive and discriminate a wide array of auditory frequencies have resulted in the formation of a complex structure with examples of cellular precision at multiple levels (Manley 2017). At a gross level, the cochlea can be modeled as a logarithmic spiral (see britannica.com/science/logarithmicspiral) that is generally conserved in terms of length within individuals of the same species. But the degree of organizational precision is even more striking at the tissue and cellular levels. Extending from the base to the apex of the spiral, the organ of Corti (OC) comprises highly ordered rows of hair cells (HCs) interdigitated with similarly ordered rows of supporting cells (SCs) (Kelley et al. 2009; Groves and Fekete 2012). The number and arrangement of each cell type is nearly invariant along a given OC or between OCs in disparate mammalian species. Similarly, each HC is topped with an elegant stereociliary bundle that has a V shape. The vertices of all HCs are uniformly aligned to point toward the outer (distal/lateral/abneural) edge of the spiral. The alignment of these bundles is a wonderful example of form following function as each bundle is directionally sensitive and can only respond to deflections along the neuralabneural axis. Understanding the cellular and molecular processes that must work in concert to achieve this level of organization has long

Editors: Guy P. Richardson and Christine Petit

Additional Perspectives on Function and Dysfunction of the Cochlea available at www.perspectivesinmedicine.org

Copyright (C) 2020 Cold Spring Harbor Laboratory Press; all rights reserved; doi: 10.1101/cshperspect.a033266

Cite this article as Cold Spring Harb Perspect Med 2020;10:a033266 
been a goal of developmental and auditory biologists. Although a complete picture of how this structure forms is still emerging, our understanding of several aspects of this process has increased significantly through the use of mouse genetics and advanced microscopy. This article will review our existing understanding of several crucial processes that occur during cochlear formation and patterning and will discuss how those processes meld together to achieve such a high degree of developmental precision.

\section{INITIAL OUTGROWTH OF THE COCHLEAR DUCT}

Soon after the closure of the otic pit to form the otocyst, two outpocketings begin to extend from the dorsal and ventral poles of the otocyst (Wu and Kelley 2012). The dorsal extension will form the relatively straight endolymphatic duct, whereas the ventral extension will coil to give rise to the cochlear duct. Different regions of the duct will ultimately give rise to the three walls of the scala media: Reissner's membrane, the lateral wall including the stria vascularis and spiral ligament, and the basilar membrane comprised of the OC and inner and outer sulci. Counter gradients of Wnt and Hedgehog originating from the dorsal and ventral regions of the neural tube, respectively, play key roles in the determination of dorsal (vestibular) and ventral (auditory) identity across the axis of the otocyst (Riccomagno et al. 2002; Bok et al. 2007; Brown and Epstein 2011), but how ventral identity mediates the formation, extension, and coiling of the cochlear duct is unknown.

Lineage-tracing studies using Sox $2^{\text {creErt2 }}$ to drive expression of green fluorescent protein (GFP) indicate that the cells that initially comprise the extending duct are derived from progenitor cells located in the ventral region of the otocyst at the outset of extension (Gu et al. 2016). Moreover, the spatial distribution of different, probably lineage-restricted progenitors suggests that the general spatial pattern of cell types is established at the outset of extension. Although the specific signaling pathways that mediate overall growth of the duct are unknown, most of the cell types within the duct continue to pro- liferate through at least the early postnatal time period in the mouse (Ruben 1967; Chen and Segil 1999), suggesting that increasing cell numbers probably play a role in driving outgrowth.

In contrast with all other otic progenitor cells, the prosensory cells that give rise to the HCs and SCs that form the OC, become postmitotic by E14, at least 7 days prior to end of active outgrowth (Ruben 1967; Chen and Segil 1999; Lee et al. 2006). At this stage, the length of the duct is generally less than half of its final length, suggesting that in the mouse some prosensory cells will need to move a distance of $\sim 3000 \mu$ to reach their final position at the extreme cochlear apex (McKenzie et al. 2004; Yamamoto et al. 2009; Driver et al. 2017). Initial observations of the changes in the distribution of progenitors that occur during cochlear outgrowth led to the suggestion that a conserved morphogenetic process termed convergence and extension (CE) plays a role in prosensory outgrowth (Chen et al. 2002). In other systems, CE is characterized by the active migration of cells located at the periphery of an epithelial field toward the midline (Keller et al. 2000; Skoglund and Keller 2010; Solnica-Krezel and Sepich 2012). As cells at the periphery move inward, they intercalate between existing cells. This creates extension orthogonal to the direction of inward movement. Although initial observations were consistent with a CEmediated process, subsequent morphological analyses and time-lapse imaging indicated that prosensory extension also occurs through radial intercalation and cellular growth (Driver et al. 2017). At E14, the prosensory cell population is arranged in a highly pseudostratified epithelium with an average of 10 cells stacked between the lumenal surface and the basement membrane, with every cell within that stack extending projections that contact both the lumenal and basal surfaces (Fig. 1). Between E14 and E16, the cells undergo radial intercalation causing the stratification of the epithelium to decrease to approximately five cells, whereas the height of each cell decreases. This rearrangement has the potential to generate a force oriented orthogonal to the direction of intercalation with one possible outcome of this force generation being displacement of prosensory cells toward the apex of the 


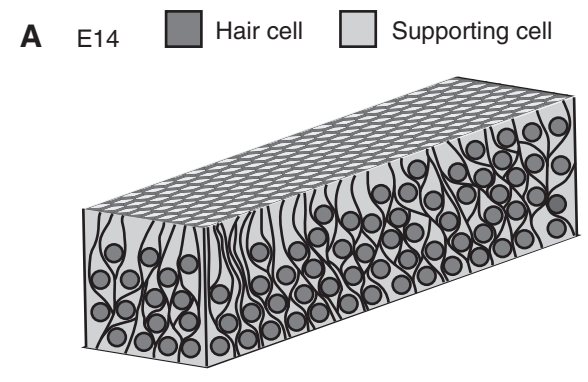

B $\quad$ E16

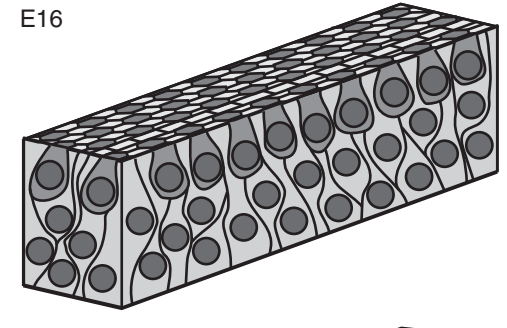

C

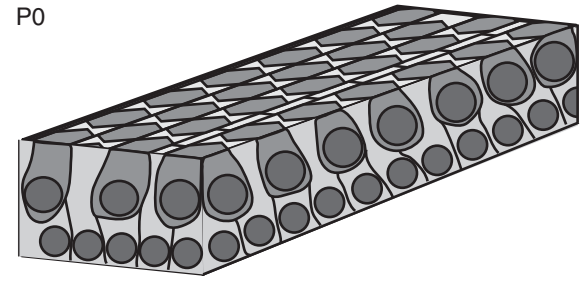

Figure 1. Changes in distribution of prosensory cells during cochlear outgrowth. Each drawing represents a region near the midbase of the cochlea. $(A)$ At E14, the epithelium is highly pseudostratified. There is no cellular organization and no morphological differentiation has occurred. (B) At E16, immature hair cells have begun to become organized into rows and stratification has decreased although more than two layers of cells are still present. Note the overall decrease in cell density as a result of cellular migration and extension. $(C)$ By $\mathrm{P} 0$, the mature cellular pattern is present with a luminal layer of hair cells resting on a basal layer of supporting cells.

cochlea. Somewhat surprisingly, the width of the prosensory domain along the neural-abneural axis is unchanged over the same time period, a result that is inconsistent with ongoing convergence. However, there is a concomitant average increase in individual cell volume of $\sim 66 \%$ ( $\pm 30 \%$ ) depending on cell type (HC vs. SC), which masks some ongoing convergence (see below). Between E16 and P0, cellular migration and intercalation decrease but cellular growth (measured as an increase in volume), in particular of the HCs, continues. These results suggest
Development and Patterning of the Cochlea

that at early time points, outgrowth is driven by a combination of cellular intercalation, convergence, and increasing cellular size, although at later time points an increase in cell size seems to be the primary driver of extension.

The core planar cell polarity (PCP) signaling pathway has been shown to regulate many processes that involve collective migration and cellular extension including neural tube closure, gastrulation, and epiboly (Goodrich 2008; Simons and Mlodzik 2008; Carreira-Barbosa et al. 2009; Skoglund and Keller 2010). Consistent with these observations, shortened cochleae have been reported for mouse lines carrying mutations in different members of the PCP pathway. In particular, mutations in Vangl2, Dsh $1+2$, Wnt5a, Dchs1, and Fat1/4 result in shorter cochleae than those in controls (Montcouquiol et al. 2003; Wang et al. 2006a,b; Qian et al. 2007; Mao et al. 2011; Saburi et al. 2012). However, other PCP mutants, such as Frz3/6 and Celsr1, which play a role in stereociliary bundle orientation (see below), were not reported to have short cochleae (Curtin et al. 2003; Wang et al. 2006b). It is not clear whether this is a result of functional redundancy, genetic compensation, an absence of a role in cochlear outgrowth, or simply restricted expression of these proteins only in HCs. Most of the PCP mutants with shortened cochleae also contain cellular patterning defects in the distal end, suggesting that outgrowth and cellular patterning are linked to some extent (see below). For many of the mutants described above, phenotypes related to both cochlear outgrowth and polarization are exacerbated on a Vangl ${ }^{L / 2 /+}$ background demonstrating genetic and potential biological interactions between many of these factors and Vangl2, although some of these effects might be caused by the dominant-negative effect of the Vangl2 ${ }^{L p}$ allele (Yin et al. 2012).

Examination of mutations affecting molecules that directly mediate changes in the cellular cytoskeleton and that may be modulated directly or indirectly through the PCP pathway have shown more extensive effects on cochlear extension. For instance, targeted deletions of the GTPase Rac1, the microtubule motor Kif3a, or IFTs Ift88, Ift20, or Ift25 or disruption of 
the nonmuscle Myosin II motor complex lead to variable shortening of the duct ( $50 \%)$ and concomitant defects in patterning that are most commonly manifested as supernumerary rows of outer (OHCs) and inner hair cells (IHCs) located at the apex (Grimsley-Myers et al. 2009; Yamamoto et al. 2009; Sipe and Lu 2011; May-Simera et al. 2015). Inhibition of Myosin II either in vitro using Blebbistatin or in vivo through expression of a dominant-negative form of Myh10 leads to significant changes in several aspects of prosensory cell morphology including cell size and the number of four-cell vertices, a marker of ongoing cellular intercalation (Driver et al. 2017). Briefly, during active cellular intercalation, the luminal patterning of cells changes. A common indicator is the formation junctions that contain more than three cells. Therefore, mapping four-cell vertices in fixed tissue can be used as a proxy for cellular intercalation events. At a subcellular level, work from $\mathrm{Lu}$ and colleagues has shown that PTK7, a receptor tyrosine kinase-like molecule that was initially identified as a noncanonical PCP protein, facilitates junctional localization of Myh10 (a Myosin II heavy chain) in developing SCs (Lee et al. 2012). This localization provides a scaffold for Myosin II-mediated contractile forces, which contract the lumenal surfaces of SCs at late embryonic stages (Ebrahim et al. 2013). Consistent with this conclusion, cochlea from mice expressing a dominant-negative Myh10 construct throughout cochlear development have SCs that show defects in lumenal contraction, a decrease in the total area at the cells luminal surface (Yamamoto et al. 2009). However, the effects of Myosin II are not limited to lumenal contraction as $M y h 10^{D N}$ cochleae also contain supernumerary rows of misshaped pillar cells. Finally, expression of $M y h 10^{D N}$ only in HCs results in smaller HCs and a shortened cochleae even though overall cellular patterning is normal (EC Driver and MW Kelley, unpubl.).

In contrast with the reverse genetic results described above, forward genetic analysis also has the potential to provide insights regarding cochlear outgrowth. In particular, a collection of human disorders referred to as cochlear hypoplasias and/or Mondini disorders (depending on severity) typically include a shortened cochleae and some degree of low-frequency hearing loss (Jackler et al. 1987; Sennaroglu and Saatci 2002). Subsequent analyses have examined cochlear structure, largely reporting a relatively normal $\mathrm{OC}$ and duct in basal regions but cystic or malformed structures toward the apex. Only a few of the causative genes for cochlear hypoplasia or a Mondini disorder have been identified. The anion transporter, SLC26A4, also known as Pendrin, underlies $~ 50 \%$ of all cases of Pendred syndrome, which typically features a Mondini dysplasia (Pourova et al. 2010; Huang et al. 2011). In these individuals, the cochlea is typically short, swollen, and distended, as are other regions of the inner ear, suggesting that the defect in cochlear outgrowth may be a result of more global defects in inner ear formation. Other genes that have been linked with shortened cochleae in humans include KCNJ10, FOXI1, POU3F4, and FGF3 (Jonard et al. 2010; Pique et al. 2014). However, as is the case for SLC26A4, the broad expression of these genes throughout the developing otocyst or periotic mesenchyme prevents inferences regarding the specific roles of these genes in cochlear outgrowth. Similarly, although rare, there are genetic mutations resulting in congenital low-frequency sensorineural hearing loss (cLFSNHL) that have been mapped to WFS1, DIAPH1, and MYO7A (Lynch et al. 1997; Bespalova et al. 2001; Cryns et al. 2003; Street et al. 2004). Although shortened cochleae have not been reported for any patients with CLFSNHL, a potential role for the mouse ortholog Diaphanous1 in outgrowth seems possible considering its known interactions with GTPases and the cytoskeleton (Purvanov et al. 2014; Wu et al. 2015).

Finally, some patients with Pallister-Hall syndrome (PHS), which is caused by a truncating mutation in the Sonic hedgehog target gene GLI3, resulting in a partial loss of hedgehog function, have been shown to suffer from LFSNHL, and magnetic resonance imaging (MRI) analysis of the temporal bones from one patient indicate cochlear hypoplasia consistent with shortening (Driver et al. 2008; Avula et al. 2012). Analysis of Gli3 ${ }^{\Delta 699 / \Delta 699}$ mice, a model for PHS, similarly indicated a shortened cochlear duct and cochlear outgrowth assays showed de- 
fects in extension in response to inhibition of Sonic hedgehog signaling (EC Driver and MW Kelley, unpubl.). Overall, these results provide strong evidence for a role for hedgehog signaling in cochlear outgrowth. Specific deletion of Shh in the developing spiral ganglion results in a similar degree of shortening to that observed in PHS (Bok et al. 2013), suggesting that Shh originating in the spiral ganglion may act to stimulate some aspect(s) of cochlear extension although the specific roles of Shh have not been determined yet.

\section{COCHLEAR MOSAIC}

During the course of cochlear development and outgrowth, HCs and SCs become arranged in a precise mosaic. A key initial step in this process is the sorting of progenitor cells into HCs and SCs, which occurs through activation of the notch signaling pathway (Lanford et al. 1999, 2000; Kiernan et al. 2005; Brooker et al. 2006). But, analysis of cochleae from notch mutants indicates that although there is a disruption in the number of progenitors that become committed to develop as HCs, an alternating mosaic of HCs and SCs still forms (see Fig. 2) most likely as a result of the recruitment of additional SCs by developing HCs (Woods et al. 2004; Kiernan et al. 2005; Hartman et al. 2010; Pan et al. 2013). It is important to consider that notch signaling occurs concomitantly with active outgrowth. Therefore, interactions between progenitor cells, and activation of the notch pathway, can change in response to changes in cell-cell contacts. Consistent with this hypothesis is the demonstration that inhibition of cochlear outgrowth alters cell fates causing fewer cells to develop as HCs (Driver et al. 2013), suggesting that progenitor cells may use active migration as a mechanism to escape notch activation. However, this observation also suggests that cellular rearrangement occurs subsequent to determination of cell fate, raising questions regarding how HCs and SCs pattern into such a precise mosaic.

Two evolutionarily conserved transmembrane immunoglobulin-like molecules called Nectins participate in the generation of the mosaic pattern of the OC. Nectin 1 and 3 are differentially expressed on HCs and SCs, respectively,
Development and Patterning of the Cochlea

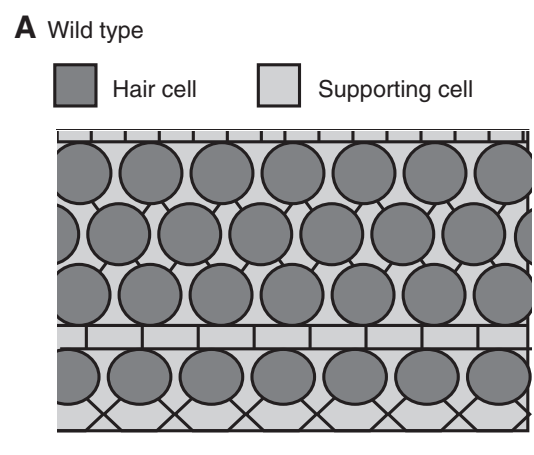

B

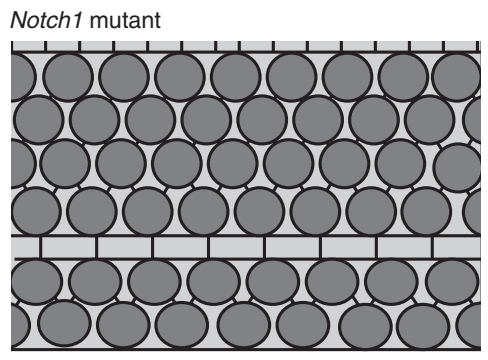

C Nectin3 mutant

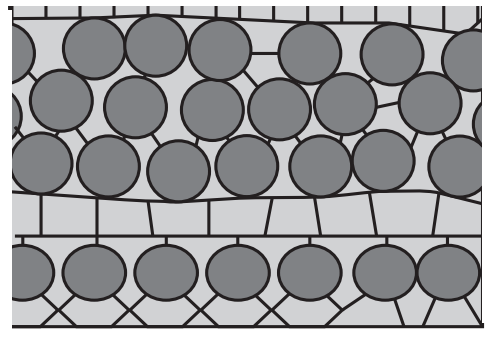

Figure 2. Effects of different mutations on cell patterning. (A) Surface view of the wild-type organ of Corti (OC), illustrating the normal pattern of hair cells and supporting cells. (B) Disruption of notch signaling, as occurs following deletion of Notch1, leads to an overproduction of hair cells but the mosaic of hair cells and supporting cells is still maintained, most likely as a result of recruitment of supporting cells by hair cells. $(C)$ In contrast, the number of hair cells and supporting cells in the OC from a Nectin 3 mutant does not significantly differ from wild type, but hair cells are observed to be in contact, indicating a disruption in cellular patterning.

and can bind via both homo- and heterophilic interactions (Togashi 2016). Deletion of either Nectin1 or Nectin3 leads to defects in the cochlear mosaic, most commonly HC-HC contacts (Fig. 2). Although the changes in cochlear patterning in these mutant lines are largely con- 
M. Montcouquiol and M.W. Kelley

sistent with a preferential heterophilic binding between Nectin1/HC and Nectin3/SC, there are several factors to consider. In particular, the patterning defects in Nectin 1 mutants are relatively mild by comparison with the more severe phenotype observed in Nectin 3 mutants. In addition, analysis of Nectin 1 expression in Nectin $3 \mathrm{mu}-$ tants indicates a nearly complete absence of Nectin1, suggesting either an interdependence between cells or the possibility that Nectin3 is expressed in both SCs and HCs, or a non-cellautonomous role of Nectin3. Therefore, generating cell-type-specific deletions for both Nectins in HCs and/or SCs is needed to fully understand the molecular role of each protein. But, the phenotypes observed in the cochleae of these animals strongly suggest that heterophilic interactions between developing HCs and SCs are critical, consistent with these interactions being stronger than homophilic ones (Togashi et al. 2011).

\section{PLANAR CELL POLARITY AND ORIENTATION OF STEREOCILIARY BUNDLES}

As discussed, cochlear HCs serve as a unique model for the study of cellular polarity. In the early stages of differentiation, the apical region of the HC undergoes a complex morphogenic process to form and orient the mechanosensory stereociliary bundle. Each stereociliary bundle is derived from the single true cilium that exists on all epithelial cells and a cluster of microvilli that adorn the apical surface of the cell. As bundle development begins, the axoneme of the primary cilium (future kinocilium), which initially projects from the center of the apical surface of the young $\mathrm{HC}$, grows in size and migrates eccentrically toward the abneural edge of each HC (Mbiene et al. 1984; Lim and Anniko 1985; Forge et al. 1997; Lepelletier et al. 2013). By $\mathrm{P} 15$, the cilium and microvilli have remodeled to form a cohesive U-, V-, or W-shaped stereociliary bundle composed of tens to hundreds of actin-rich stereocilia arranged in precise rows to create a staircase pattern. At the vertex of each stereociliary bundle is a kinocilium, which serves as the "guidepost" for hair bundle planar orientation. The kinocilium is anchored by a basal body located at its base and positioned just below the apical membrane in an abneural notch in the cuticular plate called the fonticulus.

\section{INITIAL DISCOVERY OF THE ROLE OF PCP GENES IN STEREOCILIARY BUNDLE ORIENTATION}

A crucial role for the core PCP pathway in the orientation of stereociliary bundles was initially described in 2003, when the analysis of the cochleae of a spontaneous mutant mouse line (looptail) bearing a mutation in Vangl2, a vertebrate homolog of the Drosophila PCP gene vang, revealed formed but misoriented, stereociliary bundles (Fig. 3A) (Montcouquiol et al. 2003). Subsequent studies identified similar roles for other vertebrate homologs of Drosophila core PCP genes, including Celsr1, Dishevelled, and Frizzled (Curtin et al. 2003; Wang et al. 2005, 2006b). Further studies indicated that the establishment of PCP in the cochlear and vestibular epithelia depended on the planar asymmetric localization of core PCP proteins to specific sides of HC and SC (Fig. 3B), similar to the process that occurs in Drosophila (Adler 2012).

Vangl2 and Prickle 2 localize at boundaries between the neural sides of HCs and the abneural sides of SCs, and opposite to Frizzled 3 and 6, whereas Dishevelled 2 and 3 localize at the distal side of the HC between the abneural sides of HCs and the neural sides of SCs (Montcouquiol et al. 2006; Wang et al. 2006b; Deans et al. 2007; Yin et al. 2012; Ezan and Montcouquiol 2013). More detailed examinations of the phenotypes in specific core PCP mutants have shown differential sensitivity based on HC type or position. For instance, although third-row OHCs are most affected in Vangl2 mutants, in Fz3/6 double mutants IHCs show the most severe degree of misorientation (Fig. 3A,C) (Montcouquiol et al. 2003; Wang et al. 2006b; Yin et al. 2012). But, although bundles are misoriented in core PCP mutants, the bundles themselves still develop with a characteristic polarity, as illustrated by the formation of a " $V$ " or " $W$ " shape, and the kinocilium still migrates to the cell cortex, indicating that the intracellular polarity is not disrupted. This phenotype contrasts with other 

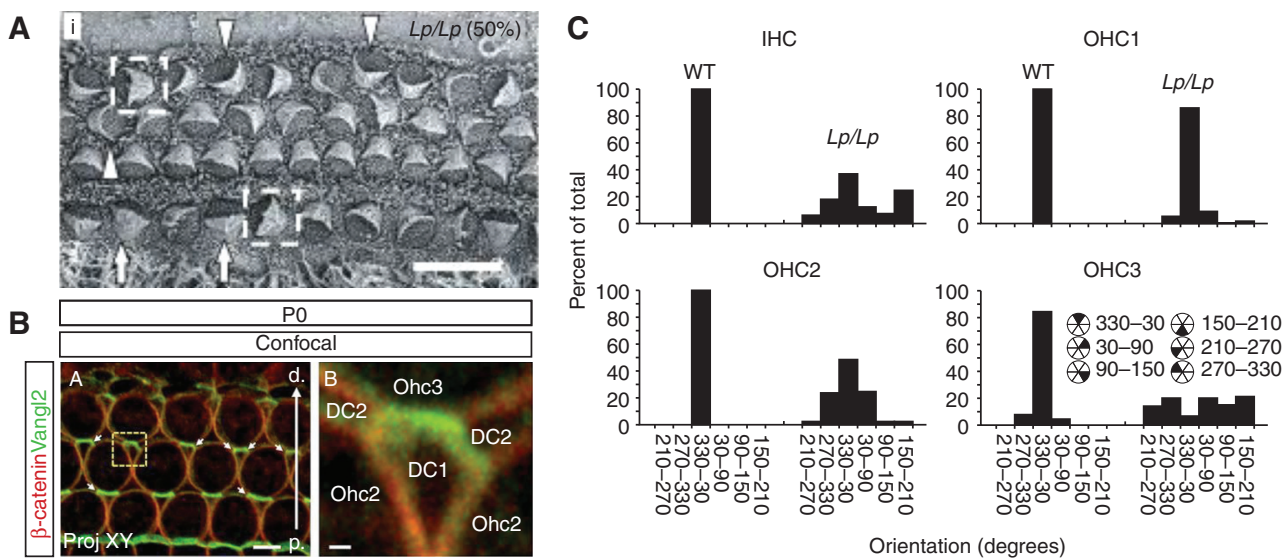

Figure 3. Vangl2 regulates stereociliary bundle orientation in the cochlea. (A) Scanning electron micrograph of the organ of Corti from a Vangl2 ${ }^{L / L P}$ mouse at E18.5. Stereociliary bundles show varying degrees of misorientation (indicated by arrowheads, arrows, and boxed cells). (B) Confocal image of the surface of the outer hair cell $(\mathrm{OHC})$ region from the organ of Corti of a P0 mouse. Vangl2 is localized to the junctions between the distal sides of Deiters cells (DCs) and the proximal sides of OHCs. (C) Frequency histograms illustrating the distribution of bundle orientations, based on cell type, in control and $V a n g l 2^{L p / L p}$ cochleae at E18.5. Note that although bundles in wild-type (WT) animals show a limited distribution centered around the optimal $\left(0^{\circ}\right)$ orientation, in Vangl2 ${ }^{L p / L p}$ bundles show varying degrees of misorientation based on location. Scale bars, $10 \mu \mathrm{m}(A) ; 4 \mu \mathrm{m}(B$, left); $0.5 \mu \mathrm{m}(B$, right). IHC, Inner hair cell. (Panels $A$ and $C$ from Montcouquiol et al. 2003; reproduced, with permission, from Springer Nature. Panel $B$ from Giese et al. 2012; reproduced, with permission, from the authors.)

mutations that may lead to changes in both bundle orientation and shape. These include the genes within the Ush1 complex (Lefevre et al. 2008) as well as genes that underlie ciliopathic diseases such as Bardet-Biedl syndrome (BBS), Meckel-Gruber syndrome (MKS), and Alström syndrome (Alms) (May-Simera 2016). All of these disorders include hearing loss and therefore reflect the functional role of orientation. However, because bundle shape and/or mechanotransduction are also altered with these syndromes, it is not possible to determine how much of the auditory pathology should be attributed to defects in orientation. More recently, the mechanisms that mediate intrinsic cellular polarity have identified and will be discussed below.

\section{GPSM2-LGN AND PAR COMPLEXES DETERMINE KINOCILIUM MOVEMENT AND HAIR BUNDLE SHAPE}

As discussed, the first indication of bundle polarization is the centrifugal migration of the developing kinocilium toward the abneural edge of each HC. This process begins around E15, well after the initial commitment of HCs, which occurs about 2 days earlier (E13) based on expression of the HC markers Atoh1 and Myosin 6 (Chen et al. 2002; Montcouquiol et al. 2003). An aster of microtubules originating from the base of the kinocilium (the basal body) and extending beneath and parallel to the apical surface or each HC was described in newborn animals (Hallworth et al. 2000). However, this microtubule aster has also been observed as early as E13.5 (M Montcouquiol, unpubl.), at which time the primary cilium/immature kinocilium has not yet migrated to the periphery of the cell. This suggests the existence of a microtubule-organizing center (MTOC) (Hallworth et al. 2000) that could guide the direction of basal body and kinocilial migration. In 2013, the similarity between these structures and microtubule-based asters that form during mitosis led to an examination of the role of the spindle-related heterotrimeric G protein $\alpha$-subunit $/ \mathrm{G}_{\alpha \mathrm{\alpha i} 3}$ in bundle development and orientation (Ezan and Montcouquiol 2013; Ezan et al. 2013; Tarchini et al. 2013).

Ezan et al. (2013) observed an abneural crescent of $\mathrm{G}_{\alpha \mathrm{i} 3}$ in IHCs in the apical turn of E15.5 
M. Montcouquiol and M.W. Kelley

rat cochleae (the approximate equivalent to an E13.5/E14 in a mouse) and in OHCs a day later. Initially, $\mathrm{G}_{\alpha \mathrm{i} 3}$ protein covers the entire apical surface of the HCs, within which there is a central cilium. The crescent of $G_{\alpha i 3}$ is then formed, before the migration of the cilium, apparently playing an instructive role in the subsequent migration of the kinocilium (Fig. 4A,B). A similar dynamic profile was reported shortly after for the G-protein-signaling modulator 2 (Gpsm2; also known as LGN in mammals or Pins in invertebrates), a well-known and conserved partner of $\mathrm{G}_{\alpha \mathrm{i}}$, and for Inscuteable (Insc), a binding partner of Pins (Tarchini et al. 2013). The same two studies revealed that there was, on the opposite side of the cell, a neural complex composed of the atypical protein kinase $\mathrm{C}(\mathrm{aPKC})$ protein and one of the members of the partitioning-defective (Par) family, Par6b. This complex abuts the shortest stereocilia row of the bundle. Therefore, Gpsm2-LGN/G oij $_{2} / \mathrm{Insc}$ and aPKC/ Par6b effectively establish asymmetric boundaries along the apical surface of each developing $\mathrm{HC}$ to delineate the shape of the hair bundle. In at least one study, both complexes were also shown to be asymmetrically enriched at cellular

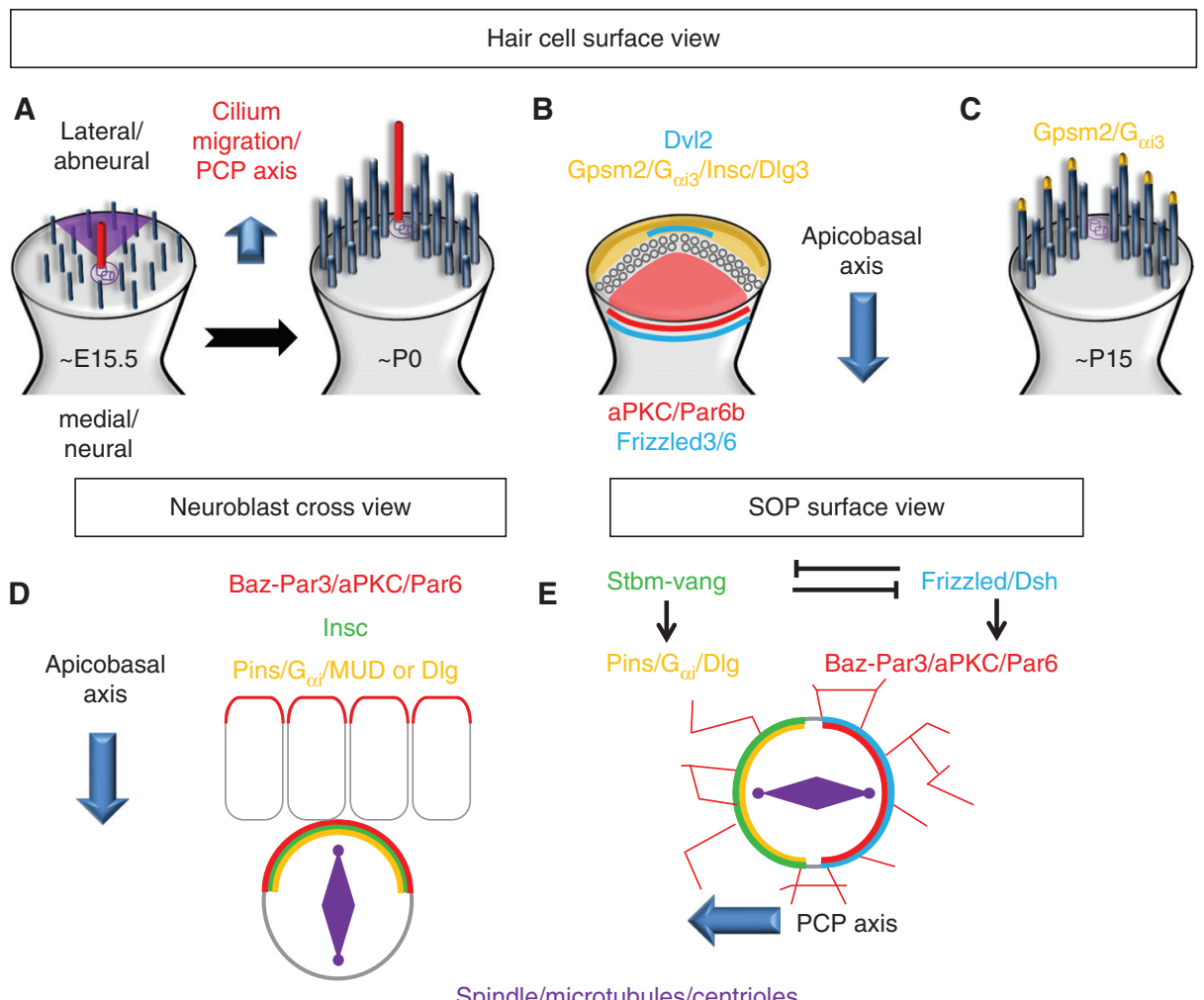

Figure 4. Differences in Gpsm2-Pins/G $\mathrm{G}_{\alpha \mathrm{i}}$ localization between hair cells, Drosophila neuroblasts, sensory organ precursor (SOP). $(A, B)$ In hair cells, between E15.5 to P0, the migration of the kinocilium toward the lateral/ abneural side is instructed by an apical accumulation of $\mathrm{Gpsm} 2 / \mathrm{G}_{\alpha \mathrm{\alpha i}} / \mathrm{Insc} / \mathrm{Dlg}$, whereas an aPKC/Par6 complex is restricted to the medial/neural side. Of note, Daple expression is restricted to the apicolateral junction (darker orange/brown). (C) In later stages, Gpsm $2 / \mathrm{G}_{\alpha \mathrm{i} 3}$ accumulates at the tip of the longest stereocilia. $(D)$ In delaminating neuroblasts, the Par-6/Baz-Par-3/aPKC and the Pins $/ \mathrm{G}_{\mathrm{\alpha i}} / \mathrm{Mud}$ or Dlg complexes colocalize at the apical cortex and control the apicobasal orientation of the spindle. Pins $/ \mathrm{G}_{\alpha \mathrm{i}} / \mathrm{Mud}$ or Dlg are recruited to the apical cortex through the presence of Insc. (E) In SOPs, Strabismus (Stbm)-Vang, localizes to the anterior cortex and recruits Pins, where they both work to restrict the Par complex to the posterior cortex, maintaining the spindle orientation parallel to the surface of the epithelium. PCP, planar cell polarity. 
tight junctions (TJs) located just below and lateral to the apical membrane (Ezan et al. 2013). Inhibition of Gpsm-LGN or $\mathrm{G}_{\alpha \mathrm{i}}$ through either genetic mutations or exposure to PTX resulted in three major phenotypes (with varying degrees of severity): (1) misorientation of the hair bundle (similar to a classic PCP phenotype); (2) disruption of the centrifugal migration of the kinocilium (in extreme cases the kinocilium remained in the center of the cell); and (3) abnormally shaped (mostly flat or split) stereociliary bundles. The results of these two studies support a model in which the molecular machinery required to direct mitotic spindle orientation during asymmetric cell division is also adapted to control kinocilium migration and hair bundle shape and orientation (see below).

An intriguing result from the studies described above was the observation that Gpsm2$\mathrm{LGN} / \mathrm{G}_{\alpha \mathrm{i}}$ complexes were localized to two different regions of each $\mathrm{HC}$, the apical crescent and the TJ, suggesting the possibility that these two pools serve different functions. Access to different protein partners could lead to activation of different signaling pathways with unique functional consequences. For example, the apical proteins could limit the neural and abneural expansion of the stereociliary bundle and determine its final shape, whereas the TJ-localized complex could control the anchoring of and the pulling forces on the microtubule aster and, eventually, the final position of the kinocilium (see below). However, because these processes occur in the same cell and with limited temporal separation, it may be very difficult to dissociate the two effects. Although the factors that direct/ limit the distribution of Gpsm2-LGN/G $\mathrm{G}_{\alpha i} \mathrm{com}$ plexes have not been determined, deletion of Insc leads to a marked decrease in the accumulation of Gpsm2-LGN and $G_{\alpha i}$ in the apical crescent, suggesting a role for Ins in this process (Tarchini et al. 2016).

\section{CANONICAL AND NONCANONICAL PATHWAYS}

It is important to consider that noncanonical interactions of $\mathrm{G}$ proteins that involve direct interactions with cytoskeletal elements bypass classical signaling pathways (Ahmed and Angers 2013). One example of such a noncanonical pathway is the role of $G_{\alpha i}$ in the regulation of the mitotic spindle during cell division (Cho and Kehrl 2008; Gönczy 2008). In this case, the GDP-bound form of $G_{\alpha}$ rather than the GTPbound is the important form in force generation. In contrast with canonical $\mathrm{G}_{\alpha}$-signaling, interaction with a 7-TM receptor is replaced by an intracellular guanine nucleotide exchange factor (GEF) such as Ric8 that activates $\mathrm{G}_{\mathrm{\alpha i}} / \mathrm{o}$ (Tall and Gilman 2005; Wilkie and Kinch 2005). Importantly, pertussis toxin blocks the binding of Ric8 A to $G_{\alpha i}$, preventing its GEF activity for $G_{\alpha i}$ (Woodard et al. 2010). Thus, PTX does not simply prevent the $G_{\alpha}$ proteins from interacting with their cognate 7-TM receptors but also blocks the binding of Ric- $8 \mathrm{~A}$ to $\mathrm{G}_{\alpha \mathrm{i}}$, thus preventing its GEF activity for $G_{\alpha i}$.

Recently, deletion of Daple, another GEF, was shown to cause significant disruptions in kinocilium movement and hair bundle orientation and shape (Siletti et al. 2017). Daple was identified as a Dvl-binding protein and is asymmetrically located on the lateral/abneural side of HCs with Dvl2 (although possibly not in overlapping domains) but was not detected at the apical membrane crescent. The investigators suggested that the protein could be the link between core PCP and Gpsm $2 / \mathrm{G}_{\alpha \mathrm{i}}$ signaling in the cochlear epithelium. Although this hypothesis is appealing, many questions remain to be addressed. For instance, Aznar and colleagues (2018) showed that Daple and the PDZ-binding motif (PDZ-BM) of Fz compete for binding to the PDZ-domain of Dvl, whereas Dvl and $G_{\alpha i}$ compete for two distinct modules on Daple. The formation of a Fz/Dvl/Daple complex leads to the generation of a GTP-bound form of $\mathrm{G}_{\alpha}$, the "classical" activated form of $\mathrm{G}_{\mathrm{\alpha i}}$. This would suggest that Daple (maybe with Ric8) counteracts the function of Gpsm $2 / \mathrm{G}_{\alpha \mathrm{i}}-\mathrm{GDP}$, by controlling dynamically the cycling of $\mathrm{G}_{\alpha \mathrm{i}}$ from a GDP to a GTP form. However, an important factor in this scenario would be the identity of a Frizzled receptor on the lateral side of developing HCs. Fz3 and Fz6 have been shown to be expressed on the medial pole of HCs but do not have a classical PDZ-BM, and remain asymmetrically localized 
M. Montcouquiol and M.W. Kelley

in Daple mutants (as is Vangl2), whereas to date, no Frizzleds are known to be expressed on the lateral sides (Ezan and Montcouquiol 2013). Messenger RNAs (mRNAs) for several Frizzleds, including Fz1, 2, 4, and 9, have been reported to be present in the cochlea but localization of protein has not been examined because of a lack of appropriate antibodies. Further, the phenotypes of $D v l$ (or $F z$ ) mutants differ from Daple mutants, both in terms of hair bundle orientation and cochlear extension, suggesting more complicated interactions between the two proteins that could include roles for different Dvls ( possibly mediated by Daple) in both tissue PCP and cell-autonomous polarization.

An additional consideration is the physical localization of the different components. Gpsm2, $\mathrm{G}_{\alpha \mathrm{i} 3}, \mathrm{aPKC}$, and PAR6 are all located in the apical HC membrane and at the level of TJs, whereas the core PCP protein Vangl2 is located more basally in the adherens junction region (Ezan et al. 2013). Daple appears to be somewhat overlapping but mostly below the TJ (based on ZO-1 labeling), whereas Dvl2 is below Daple, and none of them are at the apical membrane (Siletti et al. 2017; Sipe et al. 2013). Although the detection of all of these proteins is challenging, and an absence of staining does not prove an absence of expression, it will be important to determine the degree of physical overlap in developing HCs.

\section{ORIENTED CELL DIVISION AND HAIR CELL PCP: A CONSERVED MOLECULAR TOOLBOX}

The Par family of cell polarity proteins (Par3/ Par6/aPKC) plays prominent roles in regulating the formation and maintenance of apicobasal (A/B) polarity in epithelial cells (Tepass et al. 2001; Hirose et al. 2002; Rolls et al. 2003; Hutterer et al. 2004). In a typical polarized epithelial mammalian cell, the aPKC-Par3-Par6 complex has an asymmetric apical distribution, with Par3 distinctly localized to TJs, whereas aPKC/Par6 distinctly localized to TJs and aPKC/Par6 are localized more apically (above the TJ on the apical surface) (Hirose et al. 2002; Harris and Peifer 2005; Martin-Belmonte et al. 2007; Bryant and
Mostov 2008; Morais-de-Sá et al. 2010). However, the Par proteins were originally identified in Caenorhabditis elegans as regulators of asymmetric cell division (Kemphues et al. 1988; Kemphues 2000). Par3, aPKC, and Par6 transiently accumulate asymmetrically during the oriented division of cells in at least three major systems (and many more): the one-cell embryo of $C$. elegans, the neuroblasts (NBs) of the Drosophila central nervous system, and the sensory organ precursors (SOPs) of the peripheral nervous system. Pins and its binding partner, $G_{\alpha i}$, do not appear to be required for $\mathrm{A} / \mathrm{B}$ polarity but interact with the Par complex during cell division to provide important asymmetric cues for the attachment and the control of the position of the mitotic spindle during mitosis.

During Drosophila NB division, Bazooka (Baz, Par-3 in other species), Par6, and aPKC act as an apical cue inherited from the epithelium to establish asymmetry by recruiting Insc via binding to Par3, which in turn recruits Pins to the apical side of the NB (Fig. 4D). Binding of Insc to Pins triggers a conformational switch enabling the relocation of $\mathrm{G}_{\mathrm{\alpha i}-\mathrm{GDP}}$ into the complex (Schober et al. 1999; Wodarz et al. 1999; Schaefer et al. 2000, 2001; Yu et al. 2000). The tetratricopeptide (TPR) domains of Pins can then associate with the microtubule-binding protein mushroom body defect (Mud in invertebrates)/NUMA in vertebrates). The binding of Insc to Pins appears to be exclusive to its interaction with Mud/NUMA, resulting in a shift from a Par/Insc/Pins/ $\mathrm{G}_{\text {oi } 3}$ recruiting complex to a Pins $/ \mathrm{G}_{\alpha i} / \mathrm{NUMA}$ pulling complex (Culurgioni et al. 2011). The Pins/G $\mathrm{G}_{\alpha \mathrm{i} 3-\mathrm{GDP}} / \mathrm{NUMA}$ complex is required to capture astral microtubules, orient the mitotic spindle, and exert pulling forces, via binding to the microtubule motor dynein/dynactin, which provides a sliding anchorage for depolymerizing microtubules, whose shrinkage pulls the connected spindle pole toward the cortex (Schober et al. 1999; Wodarz et al. 1999; Kaltschmidt et al. 2000; Schaefer et al. 2000; Yu et al. 2000). The pulling complex is also comprised of Lis-1 and p21-activated kinase (PAK) (Siller and Doe 2008; Bompard et al. 2013), which appears to be conserved in HCs as recently reviewed by Lu and Sipe (2016). 
An alternative and partially redundant Insc/ Par-independent pathway was also described in the Drosophila NB. In this case, an asymmetrical Pins/Dlg/Khc73 complex made of the plus-enddirected microtubule motor protein kinesin heavy chain 73 (Khc-73 or GAKIN in mammals), the membrane-associated guanylate kinase (MAGUK) protein, and the tumor-suppressor protein Discs large (Dlg) forms (Fig. 4C) (Siegrist and Doe 2005). Dlg directly binds Pins after the phosphorylation of Pins by the mitotic kinase Aurora-A (Johnston et al. 2009), and then binds to and activates Khc73. The Dlg/ Khc73 complex contributes to a microtubule-induced establishment of Pins polarity, while polarized Pins/Dlg/Khc73 serve as a capture site for dynamic astral microtubules. Interestingly, imaging of the cochlea of a transgenic mouse line that constitutively expresses a Venus fluorescent protein fused to the amino terminus of Dlg3 showed a GFP-tagged abneural crescent, similar to Ins/Gpsm2-LGN/G $\mathrm{G}_{\alpha \mathrm{i}}$, suggesting that a similar mechanism is also at play during kinocilium migration and bundle maturation (Gegg et al. 2014). However, mutation of another member of the Dlg family, Dlg-1, resulted in very mild (if any) hair bundle defects in the cochlear epithelium, suggesting functional redundancy ( $\mathrm{Ri}$ vera et al. 2013). The absence of reliable antibodies for Dlg-1 prevents confirmation of this hypothesis at the moment.

Regarding Par3, discrepancies in its localization have been reported (Ezan et al. 2013; Tarchini et al. 2013). Abneural location together with Insc would suggest a NB-like mechanism with a Par3/Ins/Pins/ $G_{\alpha i}$ complex acting on microtubules. However, in NBs, Par3 (together with Par6/aPKC) colocalize with Pins $/ G_{\alpha i}$, something that was not observed in $\mathrm{HCs}$ by either group. Instead, in $\mathrm{HCs}, \mathrm{Gpsm} 2 / \mathrm{G}_{\alpha \mathrm{i}}$ are localized opposite to aPKC/Par6 in a pattern that is similar to that which occurs in SOPs (Fig. 4E). In this context, $G_{\alpha i}$ can localize directly to the plasma membrane through myristylation (Cho and Kehrl 2008; Gönczy 2008; Thyagarajan et al. 2011). Also, Drosophila SOP cells are specified in a polarized epithelium, but while they divide asymmetrically they ignore the $\mathrm{A} / \mathrm{B}$ polarity from the epithelium and instead orient along a
PCP axis (Lu et al. 1999; Bellaïche et al. 2001). The SOP planar mitotic spindle orientation then depends on and responds to core PCP protein asymmetry such as Frizzled (Fz)/Dishevelled (Dsh/Dvl) colocalizing with Baz-Par3/aPKC/ Par6, whereas Strabismus/van Gogh (Stbm/ Vang) and Prickle (Pk) colocalize with Pins/ $\mathrm{G}_{\alpha \mathrm{i}}$ on the opposite side (Goodrich and Strutt 2011; Morin and Bellaïche 2011). This is similar to the OC, with an already established A/B polarity and the presence of early core PCP cues (Montcouquiol et al. 2003; Ezan and Montcouquiol 2013). More recently, F. Schweisguth's group showed that core PCP signaling is the initial symmetry-breaking signal for the planar polarization of Par proteins in SOPs, suggesting that the epithelium becomes planar polarized at early stages, after which SOP fate is determined allowing Baz, Par6, and aPKC to read the PCP information from the tissue and to asymmetrically localize (Besson et al. 2015). A similar model has been proposed in the cochlear epithelium where in the absence of PCP signaling the kinocilium can migrate to the abneural side of the HC (cell-autonomous PCP), but the coordination of the orientation of the $\mathrm{HC}$ within the tissue (non-cell-autonomous or tissue PCP) is disrupted because the Par complex is missing global core PCP cues (for review, see Ezan and Montcouquiol 2013).

Altogether, these observations show that the HC has remarkably adapted the molecular machinery used during orientated cell division of invertebrates to mediate a different developmental event, the polarization of a structure, the stereociliary bundle, in a postmitotic cell.

\section{PCP, CILIA, AND TRAFFICKING}

Defects in kinocilia migration and bundle formations have also been observed in the inner ear epithelia of targeted mouse mutants for three intraflagellar transport (IFT) genes (Jones et al. 2008; Sipe and Lu 2011; May-Simera et al. 2015). Flattened or misshapen/circular bundles that can be separated from the kinocilia are also observed in mouse mutants for genes implicated in human ciliopathies, which include BBS, MKS, and Alms (May-Simera 2016). In addition, mu- 
M. Montcouquiol and M.W. Kelley

tations in $M k k s$ or $B b s 8$ affect the apical distribution of $\mathrm{G}_{\alpha \mathrm{i}}$ (Ezan et al. 2013; May-Simera et al. 2015). This suggests a link between the basal body, or the machinery around it, and the targeting of $\mathrm{G}_{\alpha \mathrm{i}}$ at the apical membrane. Consistent with this, robust protein trafficking is observed at the base of cilia in all cells, including HCs, as illustrated by the accumulation of Rab11 in the basal body area of the kinocilium (Kirjavainen et al. 2015). The importance of trafficking machinery (regardless of its relation to the kinocilium) for PCP was recently emphasized by the work of Jagger and colleagues, using a Sorcs 2 (Sortilin-related VPS10 domain-containing receptor 2) mutant (Forge et al. 2017). Sorcs2 belongs to a family of proteins involved in protein trafficking and intracellular/intercellular signaling with a primary role in the sorting of cargos from endosomes to the trans-Golgi network or to the cell surface (Reitz 2015). The phenotypes observed in Sorcs 2 mutants are similar to, but more severe than those of Gpsm2 or $G_{\alpha i}$ mutants, including misplacement of the kinocilium or abnormalities in bundle morphology. Critically, disruption of Sorcs 2 expression leads to an almost complete absence of Gpsm2-LGN and $\mathrm{G}_{\mathrm{\alpha i} 3}$ in the apical domain of the $\mathrm{HC}$, while aPKC is no longer distributed asymmetrically. The punctate and vesicular immunolocalization of the protein is consistent with a role of Sorcs2 in the directed sorting of Gpsm2-LGN/G $\mathrm{G}_{\alpha \mathrm{i}}$ to the apical domain of the HC. Altogether, these results show that the establishment of PCP within the inner ear epithelia requires the coordination and the integration of complex molecular mechanisms including A/B polarity, trafficking, and cilium-related machinery.

\section{GPSM2-LGN/G ${ }_{\alpha i 3}$ SIGNALING: ADDITIONAL ROLES BEYOND MICROTUBULE REGULATION}

In humans, mutations in GPSM2 (OMIM\# 604213 ) result in a rare neurological disorder called Chudley-McCullough syndrome (CMCS), which is associated with congenital-to-prelingual deafness and developmental brain anomalies (Doherty et al. 2012). Similarly, mice with a targeted mutation in Gpsm 2 are profoundly deaf at P17 (Bhonker et al. 2016). Two recent studies showed that the observed auditory deficits and the neurological phenotypes in both patients and mouse mutants are probably not a result of the classical, tubulin-dependent role of the Gpsm2/ $\mathrm{G}_{\alpha \mathrm{i} 3}$ complex (Tarchini et al. 2016; Mauriac et al. 2017).

By generating different conditional mutants for both Gpsm 2 and $G_{\alpha i 3}$, these studies showed that the elongation of the actin-rich stereocilia in the cochlear and the vestibular system, in particular those of the IHCs, is inhibited in the absence of Gpsm2, $G_{\alpha i 3}$, or, more surprisingly, when all three $G_{\alpha i} s$ were blocked through expression of pertussis toxin PTX in HCs. As a result, mechanotransduction is defective in these HCs leading to a disruption in hearing and balance. Remarkably, this result was confirmed in vitro using pertussis toxin treatments to block $\mathrm{G}_{\alpha \mathrm{i}}$ function (Mauriac et al.2017). The studies further showed that both $\mathrm{Gpsm} 2$ and $\mathrm{G}_{\mathrm{\alpha i} 3}$ proteins accumulate at the tip of the longest stereocilia, before initial elongation (Fig. 4C). This "tip domain" is a small region at the extremity of the stereocilium where elongation occurs by the addition of actin monomers at the barbed ends (plus ends) of the filaments (Tilney et al. 1981). Mauriac et al. identified the adaptor Whirlin (a member of the Usher protein network) as a new Gpsm2 interactor that binds to the amino-terminal region of the protein, and establishes a complex that also includes unconventional Myosin15 and Eps8 (Mauriac et al. 2017). This complex is required for the transport of Gpsm2 and $G_{\alpha i 3}$ to the tip of the stereocilia but does not play a role in the earlier localization of $\mathrm{Gpsm} 2 / \mathrm{G}_{\mathrm{\alpha i} 3}$ to the fonticulus (Mauriac et al. 2017). Importantly, Insc does not appear to participate in this mechanism (Tarchini et al. 2016). These results show that the targeting of $\mathrm{Gpsm} 2 / \mathrm{G}_{\alpha \mathrm{i} 3}$ proteins depends on different interactions and protein complexes for fonticular versus stereociliary localization.

Overall, these results show a surprising new role for $\mathrm{Gpsm} 2 / \mathrm{G}_{\alpha \mathrm{i}}$ in the regulation of actin polymerization. Mauriac et al. (2017) also suggest that a similar molecular mechanism for controlling of actin dynamics via $\mathrm{Gpsm} 2 / \mathrm{G}_{\alpha i}$ exists in neurons, modulating the actin retrograde actin flow and neuronal outgrowth, sug- 
gesting a much broader role for these proteins in cytoskeletal remodeling.

\section{SUMMARY}

The abilities of individual cells or tissues to generate asymmetry, either within a cell or across a group of cells, play crucial roles across most developmental processes. Several striking examples of these asymmetries occur during the development of the inner ear. In this article, we have highlighted two of these processes, the active outgrowth and concomitant patterning of the cochlear duct and the formation and orientation of the asymmetric stereociliary bundle of the HCs. Cochlear outgrowth occurs through a complex process of cellular intercalation, convergence, and growth. Although the molecular mechanisms that mediate these processes are still poorly understood, the core PCP pathway plays an instructive role in this process, while many of the mechanical changes in cell position or shape are dependent on Myosin II. The core PCP pathway is also known to play a role in the uniform orientation of stereociliary bundles across the entirety of different HC epithelia, including the cochlea, but, in contrast with its role in Drosophila, does not play a role in the specification of asymmetry within an individual cell. Instead, recent work from two laboratories has shown that a conserved signaling pathway originally identified through its role in the orientation of mitotic spindles regulates both the asymmetric localization of the developing kinocilia, the shape of the hair bundle, and, more surprisingly, the subsequent elongation of stereocilia. These results provide new insights regarding the factors that regulate asymmetry, polarity, growth, and patterning during cochlear development while also elucidating the etiologies of genetically based inner ear disorders, including Chudley-McCullough syndrome and Mondini dysplasia.

\section{REFERENCES}

Adler PN. 2012. The frizzled/stan pathway and planar cell polarity in the Drosophila wing. Curr Top Dev Biol 101: 131. doi:10.1016/B978-0-12-394592-1.00001-6
Ahmed SM, Angers S. 2013. Emerging non-canonical functions for heterotrimeric $\mathrm{G}$ proteins in cellular signaling. $J$ Recept Signal Transduct Res 33: 177-183. doi:10.3109/ 10799893.2013.795972

Avula S, Alam N, Roberts E. 2012. Cochlear abnormality in a case of Pallister-Hall syndrome. Pediatr Radiol 42: 1502 1505. doi:10.1007/s00247-012-2458-3

Aznar N, Ear J, Dunkel Y, Sun N, Satterfield K, He F, Kalogriopoulos NA, Lopez-Sanchez I, Ghassemian M, Sahoo D, Kufareva I, Ghosh P. 2018. Convergence of Wnt, growth factor, and heterotrimeric $\mathrm{G}$ protein signals on the guanine nucleotide exchange factor Daple. Sci Signal 11: eaao4220. doi:10.1126/scisignal.aao4220

Bellaïche Y, Radovic A, Woods DF, Hough CD, Parmentier M, O'Kane CJ, Bryant PJ, Schweisguth F. 2001. The partner of inscuteable/discs-large complex is required to establish planar polarity during asymmetric cell division in Drosophila. Cell 106: 355-366. doi:10.1016/S0092-8674 (01)00444-5

Bespalova IN, Van Camp G, Bom SJ, Brown DJ, Cryns K, DeWan AT, Erson AE, Flothmann K, Kunst HP, Kurnool $\mathrm{P}$, et al. 2001. Mutations in the Wolfram syndrome 1 gene (WFS1) are a common cause of low frequency sensorineural hearing loss. Hum Mol Genet 10: 2501-2508. doi:10.1093/hmg/10.22.2501

Besson C, Bernard F, Corson F, Rouault H, Reynaud E, Keder A, Mazouni K, Schweisguth F. 2015. Planar cell polarity breaks the symmetry of PAR protein distribution prior to mitosis in Drosophila sensory organ precursor cells. Curr Biol 25: 1104-1110. doi:10.1016/j.cub.2015.02.073

Bhonker Y, Abu-Rayyan A, Ushakov K, Amir-Zilberstein L, Shivatzki S, Yizhar-Barnea O, Elkan-Miller T, Tayeb-Fligelman E, Kim SM, Landau M, et al. 2016. The GPSM2/ LGN GoLoco motifs are essential for hearing. Mamm Genome 27: 29-46. doi:10.1007/s00335-015-9614-7

Bok J, Dolson DK, Hill P, Ruther U, Epstein DJ, Wu DK. 2007. Opposing gradients of Gli repressor and activators mediate Shh signaling along the dorsoventral axis of the inner ear. Development 134: 1713-1722. doi:10.1242/ dev.000760

Bok J, Zenczak C, Hwang CH, Wu DK. 2013. Auditory ganglion source of Sonic hedgehog regulates timing of cell cycle exit and differentiation of mammalian cochlear hair cells. Proc Natl Acad Sci 110: 13869-13874. doi:10.1073/pnas. 1222341110

Bompard G, Rabeharivelo G, Cau J, Abrieu A, Delsert C, Morin N. 2013. P21-activated kinase 4 (PAK4) is required for metaphase spindle positioning and anchoring. Oncogene 32: 910-919. doi:10.1038/onc.2012.98

Brooker R, Hozumi K, Lewis J. 2006. Notch ligands with contrasting functions: Jagged1 and Delta1 in the mouse inner ear. Development 133: 1277-1286. doi:10.1242/ dev.02284

Brown AS, Epstein DJ. 2011. Otic ablation of smoothened reveals direct and indirect requirements for Hedgehog signaling in inner ear development. Development 138: 3967-3976. doi:10.1242/dev.066126

Bryant DM, Mostov KE. 2008. From cells to organs: Building polarized tissue. Nat Rev Mol Cell Biol 9: 887-901. doi:10.1038/nrm2523

Carreira-Barbosa F, Kajita M, Morel V, Wada H, Okamoto H, Martinez Arias A, Fujita Y, Wilson SW, Tada M. 2009. 
M. Montcouquiol and M.W. Kelley

Flamingo regulates epiboly and convergence/extension movements through cell cohesive and signalling functions during zebrafish gastrulation. Development 136: 383-392. doi:10.1242/dev.026542

Chen P, Segil N. 1999. p27(Kip1) links cell proliferation to morphogenesis in the developing organ of Corti. Development 126: 1581-1590.

Chen P, Johnson JE, Zoghbi HY, Segil N. 2002. The role of Math1 in inner ear development: Uncoupling the establishment of the sensory primordium from hair cell fate determination. Development 129: 2495-2505.

Cho H, Kehrl JH. 2008. Beyond the plasma membrane: New functions for heterotrimeric G-protein signaling in asymmetric and symmetric cell division. Cell Cycle 7: 573-577. doi:10.4161/cc.7.5.5526

Cryns K, Thys S, Van Laer L, Oka Y, Pfister M, Van Nassauw L, Smith RJ, Timmermans JP, Van Camp G. 2003. The WFS1 gene, responsible for low frequency sensorineural hearing loss and Wolfram syndrome, is expressed in a variety of inner ear cells. Histochem Cell Biol 119: 247256.

Culurgioni S, Alfieri A, Pendolino V, Laddomada F, Mapelli M. 2011. Inscuteable and NuMA proteins bind competitively to Leu-Gly-Asn repeat-enriched protein (LGN) during asymmetric cell divisions. Proc Natl Acad Sci 108: 20998-21003. doi:10.1073/pnas.1113077108

Curtin JA, Quint E, Tsipouri V, Arkell RM, Cattanach B, Copp AJ, Henderson DJ, Spurr N, Stanier P, Fisher EM, et al. 2003. Mutation of Celsrl disrupts planar polarity of inner ear hair cells and causes severe neural tube defects in the mouse. Curr Biol 13: 1129-1133. doi:10.1016/S09609822(03)00374-9

Deans MR, Antic D, Suyama K, Scott MP, Axelrod JD, Goodrich LV. 2007. Asymmetric distribution of pricklelike 2 reveals an early underlying polarization of vestibular sensory epithelia in the inner ear. J Neurosci 27: 31393147. doi:10.1523/jneurosci.5151-06.2007

Doherty D, Chudley AE, Coghlan G, Ishak GE, Innes AM, Lemire EG, Rogers RC, Mhanni AA, Phelps IG, Jones SJ, et al. 2012. GPSM2 mutations cause the brain malformations and hearing loss in Chudley-McCullough syndrome. Am J Hum Genet 90: 1088-1093. doi:10.1016/ j.ajhg.2012.04.008

Driver EC, Pryor SP, Hill P, Turner J, Ruther U, Biesecker LG, Griffith AJ, Kelley MW. 2008. Hedgehog signaling regulates sensory cell formation and auditory function in mice and humans. J Neurosci 28: 7350-7358. doi: 10.1523/jneurosci.0312-08.2008

Driver EC, Sillers L, Coate TM, Rose MF, Kelley MW. 2013. The Atoh1-lineage gives rise to hair cells and supporting cells within the mammalian cochlea. Dev Biol 376: 86-98. doi:10.1016/j.ydbio.2013.01.005

Driver EC, Northrop A, Kelley MW. 2017. Cell migration, intercalation and growth regulate mammalian cochlear extension. Development 144: 3766-3776. doi:10.1242/ dev.151761

Ebrahim S, Fujita T, Millis BA, Kozin E, Ma X, Kawamoto S, Baird MA, Davidson M, Yonemura S, Hisa Y, et al. 2013. NMII forms a contractile transcellular sarcomeric network to regulate apical cell junctions and tissue geometry. Curr Biol 23: 731-736. doi:10.1016/j.cub.2013.03.039
Ezan J, Montcouquiol M. 2013. Revisiting planar cell polarity in the inner ear. Semin Cell Dev Biol 24: 499-506. doi:10.1016/j.semcdb.2013.03.012

Ezan J, Lasvaux L, Gezer A, Novakovic A, May-Simera H, Belotti E, Lhoumeau AC, Birnbaumer L, Beer-Hammer S, Borg JP, et al. 2013. Primary cilium migration depends on G-protein signalling control of subapical cytoskeleton. Nat Cell Biol 15: 1107-1115. doi:10.1038/ncb2819

Forge A, Souter M, Denman-Johnson K. 1997. Structural development of sensory cells in the ear. Semin Cell Dev Biol 8: 225-237. doi:10.1006/scdb.1997.0147

Forge A, Taylor RR, Dawson SJ, Lovett M, Jagger DJ. 2017. Disruption of SorCS2 reveals differences in the regulation of stereociliary bundle formation between hair cell types in the inner ear. PLoS Genet 13: e1006692. doi:10.1371/ journal.pgen.1006692

Gegg M, Böttcher A, Burtscher I, Hasenoeder S, Van Campenhout C, Aichler M, Walch A, Grant SG, Lickert H. 2014. Flattop regulates basal body docking and positioning in mono- and multiciliated cells. eLife 8: 3.

Giese AP, Ezan J, Wang L, Lasvaux L, Lembo F, Mazzocco C, Richard E, Reboul J, Borg JP, Kelley MW, et al. 2012 Gipc1 has a dual role in Vangl2 trafficking and hair bundle integrity in the inner ear. Development 139: $3775-$ 3785. doi:10.1242/dev.074229

Gönczy P. 2008. Mechanisms of asymmetric cell division: Flies and worms pave the way. Nat Rev Mol Cell Biol 9: 355-366. doi:10.1038/nrm2388

Goodrich LV. 2008. The plane facts of PCP in the CNS. Neuron 60: 9-16. doi:10.1016/j.neuron.2008.09.003

Goodrich LV, Strutt D. 2011. Principles of planar polarity in animal development. Development 138: 1877-1892. doi: 10.1242/dev.054080

Grimsley-Myers CM, Sipe CW, Geleoc GS, Lu X. 2009. The small GTPase Rac1 regulates auditory hair cell morphogenesis. J Neurosci 29: 15859-15869. doi:10.1523/jneurosci.3998-09.2009

Groves AK, Fekete DM. 2012. Shaping sound in space: The regulation of inner ear patterning. Development 139: 245 257. doi:10.1242/dev.067074

Gu R, Brown RM II, Hsu CW, Cai T, Crowder AL, Piazza VG, Vadakkan TJ, Dickinson ME, Groves AK. 2016. Lineage tracing of Sox2-expressing progenitor cells in the mouse inner ear reveals a broad contribution to nonsensory tissues and insights into the origin of the organ of Corti. Dev Biol 414: 72-84. doi:10.1016/j.ydbio.2016. 03.027

Hallworth R, McCoy M, Polan-Curtain J. 2000. Tubulin expression in the developing and adult gerbil organ of Corti. Hear Res 139: 31-41. doi:10.1016/S0378-5955 (99)00165-3

Harris TJ, Peifer M. 2005. The positioning and segregation of apical cues during epithelial polarity establishment in Drosophila. J Cell Biol 170: 813-823. doi:10.1083/ jcb.200505127

Hartman BH, Reh TA, Bermingham-McDonogh O. 2010. Notch signaling specifies prosensory domains via lateral induction in the developing mammalian inner ear. Proc Natl Acad Sci 107: 15792-15797. doi:10.1073/pnas. 1002827107 
Hirose T, Izumi Y, Nagashima Y, Tamai-Nagai Y, Kurihara H, Sakai T, Suzuki Y, Yamanaka T, Suzuki A, Mizuno K, et al. 2002. Involvement of ASIP/PAR-3 in the promotion of epithelial tight junction formation. J Cell Sci 115: 24852495.

Huang S, Han D, Yuan Y, Wang G, Kang D, Zhang X, Yan X, Meng X, Dong M, Dai P. 2011. Extremely discrepant mutation spectrum of SLC26A4 between Chinese patients with isolated Mondini deformity and enlarged vestibular aqueduct. J Transl Med 9: 167. doi:10.1186/14795876-9-167

Hutterer A, Betschinger J, Petronczki M, Knoblich JA. 2004. Sequential roles of Cdc42, Par-6, aPKC, and Lgl in the establishment of epithelial polarity during Drosophila embryogenesis. Dev Cell 6: 845-854. doi:10.1016/j.devcel.2004.05.003

Jackler RK, Luxford WM, House WF. 1987. Congenital malformations of the inner ear: A classification based on embryogenesis. Laryngoscope 97: 2-14. doi:10.1002/ lary.5540971301

Johnston CA, Hirono K, Prehoda KE, Doe CQ. 2009. Identification of an Aurora-A/PinsLINKER/Dlg spindle orientation pathway using induced cell polarity in S2 cells. Cell 138: 1150-1163. doi:10.1016/j.cell.2009.07.041

Jonard L, Niasme-Grare M, Bonnet C, Feldmann D, Rouillon I, Loundon N, Calais C, Catros H, David A, Dollfus H, et al. 2010. Screening of SLC26A4, FOXI1 and KCNJ10 genes in unilateral hearing impairment with ipsilateral enlarged vestibular aqueduct. Int J Pediatr Otorhinolaryngol 74: 1049-1053. doi:10.1016/j.ijporl.2010.06.002

Jones C, Roper VC, Foucher I, Qian D, Banizs B, Petit C, Yoder BK, Chen P. 2008. Ciliary proteins link basal body polarization to planar cell polarity regulation. Nat Genet 40: 69-77. doi:10.1038/ng.2007.54

Kaltschmidt JA, Davidson CM, Brown NH, Brand AH. 2000. Rotation and asymmetry of the mitotic spindle direct asymmetric cell division in the developing central nervous system. Nat Cell Biol 2: 7-12. doi:10.1038/71323

Keller R, Davidson L, Edlund A, Elul T, Ezin M, Shook D, Skoglund P. 2000. Mechanisms of convergence and extension by cell intercalation. Philos Trans R Soc Lond B Biol Sci 355: 897-922. doi:10.1098/rstb.2000.0626

Kelley MW, Driver EC, Puligilla C. 2009. Regulation of cell fate and patterning in the developing mammalian cochlea. Curr Opin Otolaryngol Head Neck Surg 17: 381387. doi:10.1097/MOO.0b013e3283303347

Kemphues K. 2000. PARsing embryonic polarity. Cell 101: 345-348. doi:10.1016/S0092-8674(00)80844-2

Kemphues KJ, Priess JR, Morton DG, Cheng NS. 1988. Identification of genes required for cytoplasmic localization in early C. elegans embryos. Cell 52: 311-320. doi:10.1016/ S0092-8674(88)80024-2

Kiernan AE, Cordes R, Kopan R, Gossler A, Gridley T. 2005. The Notch ligands DLL1 and JAG2 act synergistically to regulate hair cell development in the mammalian inner ear. Development 132: 4353-4362. doi:10.1242/dev.02002

Kirjavainen A, Laos M, Anttonen T, Pirvola U. 2015. The Rho GTPase Cdc42 regulates hair cell planar polarity and cellular patterning in the developing cochlea. Biol Open 4: 516-526. doi:10.1242/bio.20149753

Lanford PJ, Lan Y, Jiang R, Lindsell C, Weinmaster G, Gridley T, Kelley MW. 1999. Notch signalling pathway medi- ates hair cell development in mammalian cochlea. Nat Genet 21: 289-292. doi:10.1038/6804

Lanford PJ, Shailam R, Norton CR, Gridley T, Kelley MW. 2000. Expression of Math1 and HES5 in the cochleae of wildtype and Jag2 mutant mice. J Assoc Res Otolaryngol 1: 161-171. doi:10.1007/s101620010023

Lee YS, Liu F, Segil N. 2006. A morphogenetic wave of p27Kip1 transcription directs cell cycle exit during organ of Corti development. Development 133: 2817-2826. doi:10.1242/dev.02453

Lee J, Andreeva A, Sipe CW, Liu L, Cheng A, Lu X. 2012. PTK7 regulates myosin II activity to orient planar polarity in the mammalian auditory epithelium. Curr Biol 22: 956-966. doi:10.1016/j.cub.2012.03.068

Lefevre G, Michel V, Weil M, Lepelletier L, Bizard E, Wolfrum U, Hardelin JP, Petit C. 2008. A core cochlear phenotype in USH1 mouse mutants implicates fibrous links of the hair bundle in its cohesion, orientation and differential growth. Development 135: 1427-1437. doi:10.1242/ dev.012922

Lepelletier L, de Monvel JB, Buisson J, Desdouets C, Petit C. 2013. Auditory hair cell centrioles undergo confined Brownian motion throughout the developmental migration of the kinocilium. Biophys J 105: 48-58. doi:10.1016/ j.bpj.2013.05.009

Lim DJ, Anniko M. 1985. Developmental morphology of the mouse inner ear. A scanning electron microscopic observation. Acta Otolaryngol Suppl 422: 1-69.

Lu X, Sipe CW. 2016. Developmental regulation of planar cell polarity and hair-bundle morphogenesis in auditory hair cells: Lessons from human and mouse genetics. Wiley Interdiscip Rev Dev Biol 5: 85-101. doi:10.1002/wdev.202

Lu B, Usui T, Uemura T, Jan L, Jan YN. 1999. Flamingo controls the planar polarity of sensory bristles and asymmetric division of sensory organ precursors in Drosophila. Curr Biol 9: 1247-1250. doi:10.1016/S0960-9822(99) 80505-3

Lynch ED, Lee MK, Morrow JE, Welcsh PL, Leon PE, King MC. 1997. Nonsyndromic deafness DFNAl associated with mutation of a human homolog of the Drosophila gene diaphanous. Science 278: 1315-1318. doi:10.1126/ science.278.5341.1315

Manley GA. 2017. Comparative auditory neuroscience: Understanding the evolution and function of ears. JAssoc Res Otolaryngol 18: 1-24. doi:10.1007/s10162-016-0579-3

Mao Y, Mulvaney J, Zakaria S, Yu T, Malanga Morgan K, Allen S, Basson MA, Francis-West P, Irvine KD. 2011. Characterization of a Dchs1 mutant mouse reveals requirements for Dchs1-Fat4 signaling during mammalian development. Development 138: 947-957. doi:10.1242/ dev.057166

Martin-Belmonte F, Gassama A, Datta A, Yu W, Rescher U, Gerke V, Mostov K. 2007. PTEN-mediated apical segregation of phosphoinositides controls epithelial morphogenesis through Cdc42. Cell 128: 383-397. doi:10.1016/j. cell.2006.11.051

Mauriac SA, Hien YE, Bird JE, Carvalho SD, Peyroutou R, Lee SC, Moreau MM, Blanc JM, Gezer A, Medina C, et al. 2017. Defective Gpsm $2 / \mathrm{G}_{\alpha \mathrm{i} 3}$ signalling disrupts stereocilia development and growth cone actin dynamics in Chudley-McCullough syndrome. Nat Commun 8: 14907. doi:10.1038/ncomms14907 
May-Simera H. 2016. Evaluation of planar-cell-polarity phenotypes in ciliopathy mouse mutant cochlea. J Vis Exp 21: 53559.

May-Simera HL, Petralia RS, Montcouquiol M, Wang YX, Szarama KB, Liu Y, Lin W, Deans MR, Pazour GJ, Kelley MW. 2015. Ciliary proteins Bbs8 and Ift20 promote planar cell polarity in the cochlea. Development 142: 555566. doi:10.1242/dev.113696

Mbiene JP, Favre D, Sans A. 1984. The pattern of ciliary development in fetal mouse vestibular receptors. A qualitative and quantitative SEM study. Anat Embryol (Berlin) 170: 229-238. doi:10.1007/BF00318726

McKenzie E, Krupin A, Kelley MW. 2004. Cellular growth and rearrangement during the development of the mammalian organ of Corti. Dev Dyn 229: 802-812. doi: 10.1002/dvdy. 10500

Montcouquiol M, Rachel RA, Lanford PJ, Copeland NG, Jenkins NA, Kelley MW. 2003. Identification of Vangl2 and Scrb1 as planar polarity genes in mammals. Nature 423: 173-177. doi:10.1038/nature01618

Montcouquiol M, Sans N, Huss D, Kach J, Dickman JD Forge A, Rachel RA, Copeland NG, Jenkins NA, Bogani D, et al. 2006. Asymmetric localization of Vangl2 and Fz3 indicate novel mechanisms for planar cell polarity in mammals. J Neurosci 26: 5265-5275. doi:10.1523/ jneurosci.4680-05.2006

Morais-de-Sá E, Mirouse V, St Johnston D. 2010. aPKC phosphorylation of Bazooka defines the apical/lateral border in Drosophila epithelial cells. Cell 141: 509-523. doi:10.1016/j.cell.2010.02.040

Morin X, Bellaïche Y. 2011. Mitotic spindle orientation in asymmetric and symmetric cell divisions during animal development. Dev Cell 21: 102-119. doi:10.1016/j.devcel. 2011.06.012

Pan W, Jin Y, Chen J, Rottier RJ, Steel KP, Kiernan AE. 2013. Ectopic expression of activated Notch or SOX2 reveals similar and unique roles in the development of the sensory cell progenitors in the mammalian inner ear. $J \mathrm{Neu}$ rosci 33: 16146-16157. doi:10.1523/jneurosci.3150-12. 2013

Pique LM, Brennan ML, Davidson CJ, Schaefer F, Greinwald J Jr, Schrijver I. 2014. Mutation analysis of the SLC26A4 FOXI1 and KCNJ10 genes in individuals with congenital hearing loss. PeerJ 2: e384. doi:10.7717/peerj.384

Pourova R, Janousek P, Jurovcik M, Dvorakova M, Malikova M, Raskova D, Bendova O, Leonardi E, Murgia A, Kabelka Z, et al. 2010. Spectrum and frequency of SLC26A4 mutations among Czech patients with early hearing loss with and without enlarged vestibular aqueduct (EVA). Ann Hum Genet 74: 299-307. doi:10.1111/j.1469-1809. 2010.00581.x

Purvanov V, Holst M, Khan J, Baarlink C, Grosse R. 2014. Gprotein-coupled receptor signaling and polarized actin dynamics drive cell-in-cell invasion. eLife 3: e02786. doi:10.7554/eLife.02786

Qian D, Jones C, Rzadzinska A, Mark S, Zhang X, Steel KP, Dai X, Chen P. 2007. Wnt5a functions in planar cell polarity regulation in mice. Dev Biol 306: 121-133. doi:10.1016/j.ydbio.2007.03.011

Reitz C. 2015. The role of the retromer complex in agingrelated neurodegeneration: A molecular and genomic re- view. Mol Genet Genomics 290: 413-427. doi:10.1007/ s00438-014-0939-9

Riccomagno MM, Martinu L, Mulheisen M, Wu DK, Epstein DJ. 2002. Specification of the mammalian cochlea is dependent on Sonic hedgehog. Genes Dev 16: 2365-2378. doi:10.1101/gad.1013302

Rivera C, Simonson SJ, Yamben IF, Shatadal S, Nguyen MM, Beurg M, Lambert PF, Griep AE. 2013. Requirement for Dlgh-1 in planar cell polarity and skeletogenesis during vertebrate development. PLOS ONE 8: e54410. doi: 10.1371/journal.pone.0054410

Rolls MM, Albertson R, Shih HP, Lee CY, Doe CQ. 2003. Drosophila aPKC regulates cell polarity and cell proliferation in neuroblasts and epithelia. J Cell Biol 163: 10891098. doi:10.1083/jcb.200306079

Ruben RJ. 1967. Development of the inner ear of the mouse: A radioautographic study of terminal mitoses. Acta Otolaryngol Suppl 220: 221-244.

Saburi S, Hester I, Goodrich L, McNeill H. 2012. Functional interactions between Fat family cadherins in tissue morphogenesis and planar polarity. Development 139: 18061820. doi:10.1242/dev.077461

Schaefer M, Shevchenko A, Knoblich JA. 2000. A protein complex containing Inscuteable and the $\mathrm{G}_{\alpha}$-binding protein Pins orients asymmetric cell divisions in Drosophila Curr Biol 10: 353-362. doi:10.1016/S0960-9822(00) 00401-2

Schaefer M, Petronczki M, Dorner D, Forte M, Knoblich JA. 2001. Heterotrimeric G proteins direct two modes of asymmetric cell division in the Drosophila nervous system. Cell 107: 183-194. doi:10.1016/S0092-8674(01) 00521-9

Schober M, Schaefer M, Knoblich JA. 1999. Bazooka recruits Inscuteable to orient asymmetric cell divisions in $\mathrm{Dro}-$ sophila neuroblasts. Nature 402: 548-551. doi:10.1038/ 990135

Sennaroglu L, Saatci I. 2002. A new classification for cochleovestibular malformations. Laryngoscope 112: 22302241. doi:10.1097/00005537-200212000-00019

Siegrist SE, Doe CQ. 2005. Microtubule-induced Pins/ $\mathrm{G}_{\alpha \mathrm{i}}$ cortical polarity in Drosophila neuroblasts. Cell 123: 1323-1335. doi:10.1016/j.cell.2005.09.043

Siletti K, Tarchini B, Hudspeth AJ. 2017. Daple coordinates organ-wide and cell-intrinsic polarity to pattern innerear hair bundles. Proc Natl Acad Sci 114: E11170E11179. doi:10.1073/pnas.1716522115

Siller KH, Doe CQ. 2008. Lis1/dynactin regulates metaphase spindle orientation in Drosophila neuroblasts. Dev Biol 319: 1-9. doi:10.1016/j.ydbio.2008.03.018

Simons M, Mlodzik M. 2008. Planar cell polarity signaling: From fly development to human disease. Annu Rev $\mathrm{Ge}$ net 42: 517-540. doi:10.1146/annurev.genet.42.110807. 091432

Sipe CW, Lu X. 2011. Kif3a regulates planar polarization of auditory hair cells through both ciliary and non-ciliary mechanisms. Development 138: 3441-3449. doi:10.1242/ dev.065961

Sipe CW, Liu L, Lee J, Grimsley-Myers C, Lu X. 2013. Lis1 mediates planar polarity of auditory hair cells through regulation of microtubule organization. Development 140: 1785-1795. doi:10.1242/dev.089763 
Skoglund P, Keller R. 2010. Integration of planar cell polarity and ECM signaling in elongation of the vertebrate body plan. Curr Opin Cell Biol 22: 589-596. doi:10.1016/j. ceb.2010.07.012

Solnica-Krezel L, Sepich DS. 2012. Gastrulation: Making and shaping germ layers. Annu Rev Cell Dev Biol 28: 687-717. doi:10.1146/annurev-cellbio-092910-154043

Street VA, Kallman JC, Kiemele KL. 2004. Modifier controls severity of a novel dominant low-frequency MyosinVIIA (MYO7A) auditory mutation. J Med Genet 41: e62. doi:10.1136/jmg.2003.013557

Tall GG, Gilman AG. 2005. Resistance to inhibitors of cholinesterase $8 \mathrm{~A}$ catalyzes release of $\mathrm{G}_{\mathrm{\alpha i}}$-GTP and nuclear mitotic apparatus protein (NuMA) from NuMA/LGN/ $\mathrm{G}_{\mathrm{\alpha i}}$-GDP complexes. Proc Natl Acad Sci 102: 1658416589. doi:10.1073/pnas.0508306102

Tarchini B, Jolicoeur C, Cayouette M. 2013. A molecular blueprint at the apical surface establishes planar asymmetry in cochlear hair cells. Dev Cell 27: 88-102. doi: 10.1016/j.devcel.2013.09.011

Tarchini B, Tadenev AL, Devanney N, Cayouette M. 2016. A link between planar polarity and staircase-like bundle architecture in hair cells. Development 143: 3926-3932. doi:10.1242/dev.139089

Tepass U, Tanentzapf G, Ward R, Fehon R. 2001. Epithelial cell polarity and cell junctions in Drosophila. Annu Rev Genet 35: 747-784. doi:10.1146/annurev.genet.35.102401. 091415

Thyagarajan K, Afshar K, Gönczy P. 2011. Polarity mediates asymmetric trafficking of the G $\beta$ heterotrimeric G-protein subunit GPB-1 in C. elegans embryos. Development 138: $2773-2782$.

Tilney LG, Bonder EM, DeRosier DJ. 1981. Actin filaments elongate from their membrane-associated ends. Cell Biol 90: 485-494. doi:10.1083/jcb.90.2.485

Togashi H. 2016. Differential and cooperative cell adhesion regulates cellular pattern in sensory epithelia. Front Cell Dev Biol 4: 104. doi:10.3389/fcell.2016.00104

Togashi H, Kominami K, Waseda M, Komura H, Miyoshi J, Takeichi M, Takai Y. 2011. Nectins establish a checkerboard-like cellular pattern in the auditory epithelium. Science 333: 1144-1147. doi:10.1126/science. 1208467

Wang J, Mark S, Zhang X, Qian D, Yoo SJ, Radde-Gallwitz K, Zhang Y, Lin X, Collazo A, Wynshaw-Boris A, et al. 2005. Regulation of polarized extension and planar cell polarity in the cochlea by the vertebrate PCP pathway. Nat Genet 37: $980-985$. doi:10.1038/ng1622
Wang J, Hamblet NS, Mark S, Dickinson ME, Brinkman BC, Segil N, Fraser SE, Chen P, Wallingford JB, WynshawBoris A. 2006a. Dishevelled genes mediate a conserved mammalian PCP pathway to regulate convergent extension during neurulation. Development 133: 1767-1778. doi:10.1242/dev.02347

Wang Y, Guo N, Nathans J. 2006b. The role of Frizzled3 and Frizzled6 in neural tube closure and in the planar polarity of inner-ear sensory hair cells. J Neurosci 26: 2147-2156. doi:10.1523/jneurosci.4698-05.2005

Wilkie TM, Kinch L. 2005. New roles for $G_{\alpha}$ and RGS proteins: Communication continues despite pulling sisters apart. Curr Biol 15: R843-R854. doi:10.1016/j.cub.2005. 10.008

Wodarz A, Ramrath A, Kuchinke U, Knust E. 1999. Bazooka provides an apical cue for Inscuteable localization in Drosophila neuroblasts. Nature 402: 544-547. doi:10.1038/ 990128

Woodard GE, Huang NN, Cho H, Miki T, Tall GG, Kehrl JH. 2010. Ric-8A and $G_{i \alpha}$ recruit LGN, NuMA, and dynein to the cell cortex to help orient the mitotic spindle. Mol Cell Biol 30: 3519-3530. doi:10.1128/MCB.00394-10

Woods C, Montcouquiol M, Kelley MW. 2004. Math1 regulates development of the sensory epithelium in the mammalian cochlea. Nat Neurosci 7: 1310-1318. doi: $10.1038 / \mathrm{nn} 1349$

Wu DK, Kelley MW. 2012. Molecular mechanisms of inner ear development. Cold Spring Harb Perspect Biol 4: a008409. doi:10.1101/cshperspect.a008409

Wu J, Song M, Li T, Zhu Z, Pan J. 2015. The Rho-mDial signaling pathway is required for cyclic strain-induced cytoskeletal rearrangement of human periodontal ligament cells. Exp Cell Res 337: 28-36. doi:10.1016/j. yexcr.2015.07.016

Yamamoto N, Okano T, Ma X, Adelstein RS, Kelley MW. 2009. Myosin II regulates extension, growth and patterning in the mammalian cochlear duct. Development 136: 1977-1986. doi:10.1242/dev.030718

Yin H, Copley CO, Goodrich LV, Deans MR. 2012. Comparison of phenotypes between different vangl2 mutants demonstrates dominant effects of the Looptail mutation during hair cell development. PLoS ONE 7: e31988. doi:10.1371/journal.pone.0031988

Yu F, Morin X, Cai Y, Yang X, Chia W. 2000. Analysis of partner of inscuteable, a novel player of Drosophila asymmetric divisions, reveals two distinct steps in inscuteable apical localization. Cell 100: 399-409. doi:10.1016/S00928674(00)80676-5 


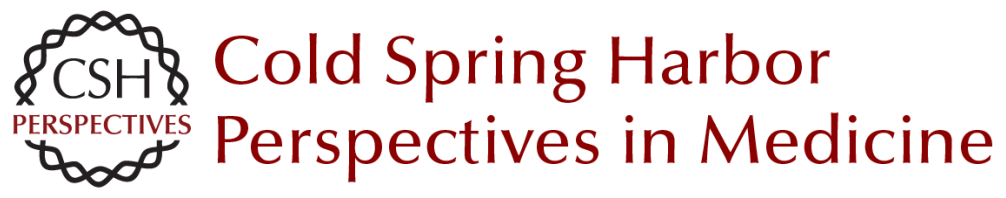

\title{
Development and Patterning of the Cochlea: From Convergent Extension to Planar Polarity
}

\author{
Mireille Montcouquiol and Matthew W. Kelley
}

Cold Spring Harb Perspect Med 2020; doi: 10.1101/cshperspect.a033266 originally published online January 7, 2019

\section{Subject Collection Function and Dysfunction of the Cochlea}

Hidden Hearing Loss: A Disorder with Multiple

Etiologies and Mechanisms

David C. Kohrman, Guoqiang Wan, Luis Cassinotti, et al.

Hair Cell Afferent Synapses: Function and

Dysfunction

Stuart L. Johnson, Saaid Safieddine, Mirna Mustapha, et al.

Active Biomechanics of Sensory Hair Bundles Dolores Bozovic

The Tectorial Membrane: Mechanical Properties and Functions Jonathan B. Sellon, Roozbeh Ghaffari and Dennis M. Freeman

The Epidemiology of Deafness Abraham M. Sheffield and Richard J.H. Smith

Toward the Optical Cochlear Implant Tobias Dombrowski, Vladan Rankovic and Tobias Moser

Outer Hair Cells and Electromotility Jonathan Ashmore

Interactions between Macrophages and the Sensory Cells of the Inner Ear Mark E. Warchol
Development and Patterning of the Cochlea: From

Convergent Extension to Planar Polarity Mireille Montcouquiol and Matthew W. Kelley

Hair-Bundle Links: Genetics as the Gateway to Function Guy P. Richardson and Christine Petit

Aminoglycoside- and Cisplatin-Induced Ototoxicity: Mechanisms and Otoprotective Strategies

Corné J. Kros and Peter S. Steyger

Function and Dysfunction of TMC Channels in Inner Ear Hair Cells

David P. Corey, Nurunisa Akyuz and Jeffrey R. Holt

Cochlear Gene Therapy

Lawrence Lustig and Omar Akil

Age-Related Hearing Loss

Michael R. Bowl and Sally J. Dawson

Inner Ear Connexin Channels: Roles in Development and Maintenance of Cochlear

Function

Fabio Mammano

A Functional Perspective on the Evolution of the Cochlea Christine Köppl and Geoffrey A. Manley

For additional articles in this collection, see http://perspectivesinmedicine.cshlp.org/cgi/collection/ 